\title{
Effect of Germination on Nutritional Composition and Functional Propertiesof Fenugreek (Trigonellafoenum-graecumLinn) Seed Flour
}

\author{
Tamiru Kasaye Atlaw ${ }^{1, *}$, Jha Yogesh Kumar², Neela Satheesh ${ }^{3}$ \\ ${ }^{1}$ Department of Food Engineering, College Technology, Debre Berhan University, Debre Berhan, Ethiopia \\ ${ }^{2}$ Food Process Engineering Program, School of Chemical and Bio Engineering, Addis Ababa Institute of Technology, Addis Ababa \\ University, Addis Ababa, Ethiopia \\ ${ }^{3}$ Faculty of Chemical and Food Engineering, Bahir Dar Inistitute of Technology, Bahir Dar University, Bahir Dar, Ethiopia
}

Email address:

tamirukasaye514@gmail.com(T.K. Atlaw)

${ }^{*}$ Corresponding author

\section{To cite this article:}

Tamiru Kasaye Atlaw, JhaYogesh Kumar, Neela Satheesh. Effect of Germination on Nutritional Composition and Functional Propertiesof Fenugreek (Trigonellafoenum-graecumLinn) Seed Flour. International Journal of Nutrition and Food Sciences.

Vol. 7, No. 3, 2018, pp. 110-115. doi: 10.11648/j.ijnfs.20180703.15

Received: April 16, 2018; Accepted: May 27, 2018; Published: June 5, 2018

\begin{abstract}
This study evaluated the effect of germination on the chemical compositionand functional propertiesof fenugreek seed flour. Germinated fenugreek flour had higher crude protein $29.89 \%$ in fenugreek flour germinated for $72 \mathrm{~h}$ followed by $29.36 \%$ in fenugreek flour germinated for $48 \mathrm{~h}$ and $27.42 \%$ in raw fenugreek flour. The crude fiber ranged from 11.349 to $14.70 \%$. But as the time of germination increased the crude fiber content slightly decreased. Fenugreek flour germinated for $48 \mathrm{~h}$ proved to be more beneficial in most mineral content than the rest of the germination periods $(p<0.05)$. Germinated fenugreek flour for 72 hrhad significantly lower contents of anti-nutritional factors. The phytate content decreased significantly $(\mathrm{p}<0.05)$ from 64.22 to 18.99 with $53.96 \%$ reduction. The study showed that fenugreek flour germinated for $72 \mathrm{~h}$ proved to be the best for highest nutrient content. The reduction of bulk density further increased as germination time increased. The control fenugreek flour have higher amount of water absorption capacity (401.86\%). On germination the WAC decreased to 250.07, 248.13 , and $245.15 \%$ at $24,48,72 \mathrm{~h}$ germination, respectively. The processed fenugreek flour had a higher oil absorption capacity in the range of $346.13-398.40 \mathrm{ml} / \mathrm{g}$, which was significantly $(\mathrm{p}<0.05)$ higher than that of control flour.
\end{abstract}

Keywords: Anti-nutrients, Composition, Fenugreek, Germinated

\section{Introduction}

Fenugreek (Trigonellafoenum-graecum L.) is an annual legume mainly used as a spice crop in many parts of the world. This crop is native to an area extending from Iran to northern India, but is now widely cultivated in China, North and East Africa, Ukraine and Greece. It is locally used as a pulse, spice and medicinal plant, and has a long history in Ethiopia. The word for fenugreek in Amharic is abish, and the seed is used as a natural herbal medicine in the treatment of diabetes[6].

Fenugreek seeds can be a good supplement to cereals because of its high protein $(25 \%)$, lysine $(5.7 \mathrm{~g} / 16 \mathrm{~g} \mathrm{~N})$, soluble $(20 \%)$ and insoluble $(28 \%)$ dietary fiber besides being rich in calcium, iron and beta-carotene [11]. However, the seeds are bitter intastedueto presence of bitter saponins, which limit their acceptability in foods [13]. It has been possibletodebitter fenugreek seeds by employing various processing methods such as soaking, germination, roasting, etc.[5].

Germination is one of the methods used in elimination of various anti-nutritional factors present in foods. It is a natural process in which dormant but viable seeds are induced to start growing into seedlings. This is the process by which amylase degrade starches into dextrin and maltose. Germination resulted in greater retention of all minerals and B-complex vitamins compared to cooking treatment in 
chickpeas [5].

Germination of the grain has important effects on the chemical composition, nutritive value, and acceptabilitycharacteristics of products for human consumption. The objective of this study therefore is to determine the effects of germination on chemicalcomposition andfunctionalproperties of fenugreek seed flour so that it could be used a potential as dietary supplement and health food.

\section{Materials and Methods}

Sources of materials: A variety of fenugreek, Hunda-01/ FG-18/, for this study was collected and transported from Sinana Agricultural Research Centre (SARC) found in Bale Robe SinanaWereda, Ethiopia.

Preparation and treatment of samples: Fenugreek seeds were cleaned, graded, sorted and washed three times using potable water. Then, the seeds were soaked in potable water for $24 \mathrm{hrs}$ at room temperature $\left(22 \pm 2^{\circ} \mathrm{C}\right)$ with a seeds: water ratio of 1:5 (w/v). The unimpeded water was discarded and the soaked seeds were rinsed twice by boiled cooled water to avoid post contamination during germination. The soaked seeds were germinated in plastic sieves covered with sterilized cloth for 24, 48 and $72 \mathrm{hrs}$ at room temperature with frequent watering. The germinated fenugreek seeds were dried in a drying oven (Beschickung-Loading, Model100-800, Memmert, Germany) at $60^{\circ} \mathrm{C}$ for $24 \mathrm{~h}$ [13] and ground to pass through 710 micron sieve (Endecotts LTD., London England) to obtain fine powder (Figure 1).
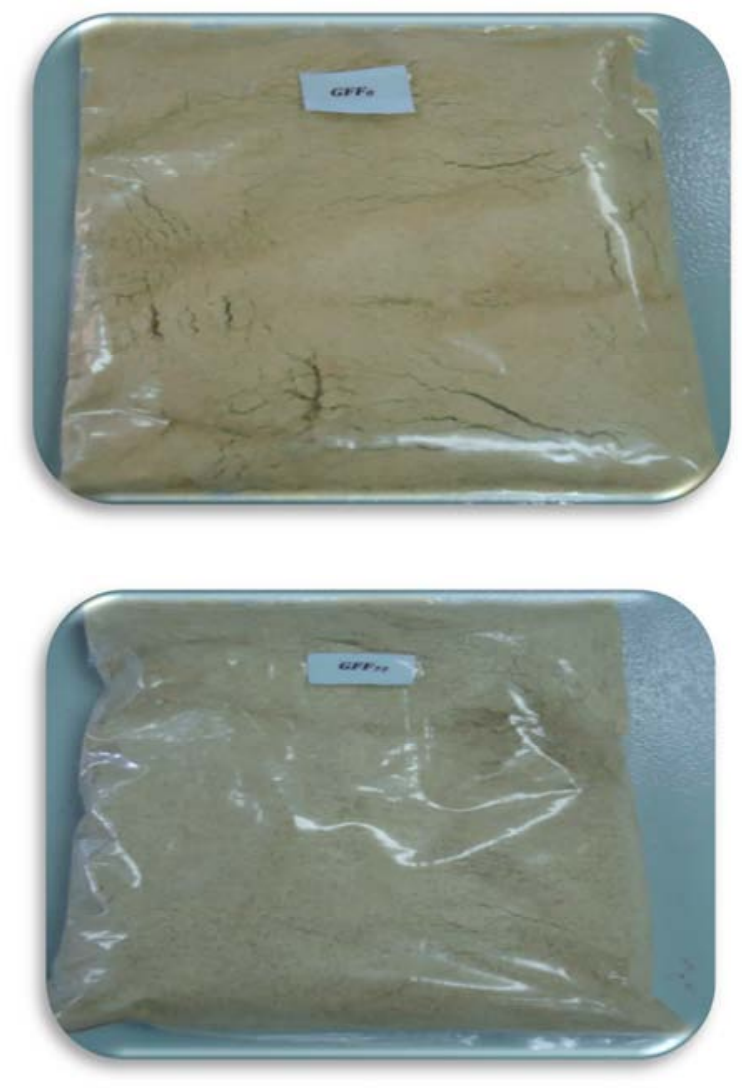
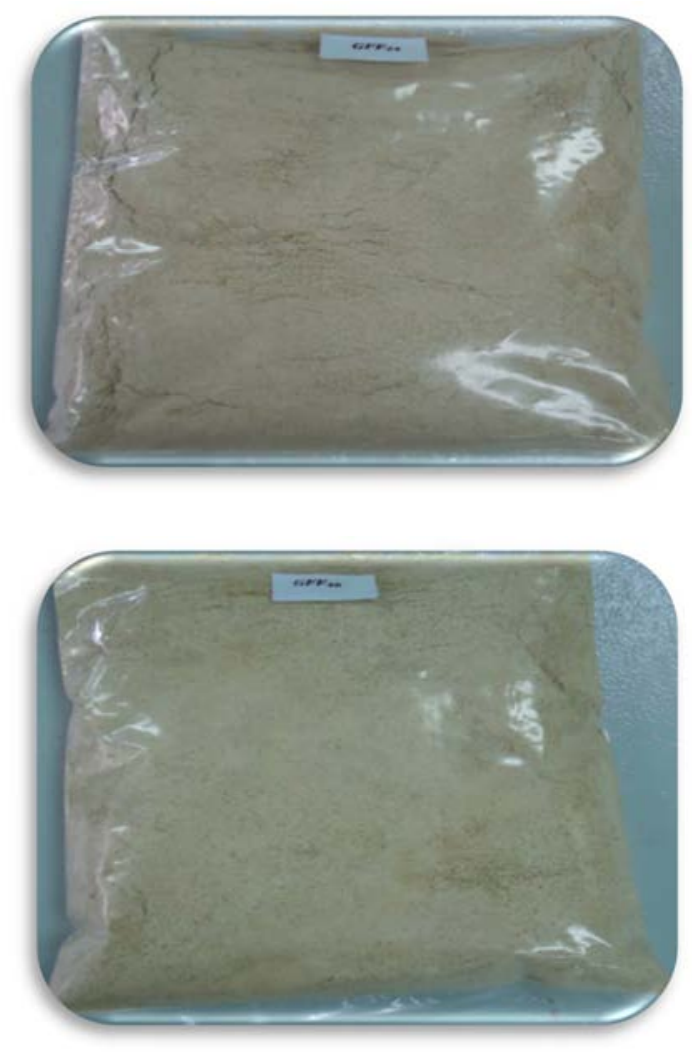

Figure 1. Prepared Fenugreek flours.

Data analysis: The quality characteristics of flours were analyzed by one way ANOVA (Analysis of Variance) using statistical tools of JMP version 5 (SAS Institute Inc., Cary, NC, USA). Significance was accepted at 0.05 level of probability $(\mathrm{p} \leq 0.05)$. Mean separation was performed by "Each pair student's t" for multiple comparison of means.

\section{Results and Discussion}

\subsection{Effect of Germination on Proximate Chemical Composition of Fenugreek Flours}

In table 1, moisture content, total ash, crude protein, crude fat, total carbohydrates of both raw and germinated fenugreek seeds are presented with respect to germination time. The crude protein content of the fenugreek seeds ranged from 26.10 to $29.89 \%$. The crude protein content of fenugreek seeds increased with germination time. The highest crude protein recorded with $72 \mathrm{~h}$ germination time and the lowest is $24 \mathrm{~h}$ germination time. This is because germination is a biotechnological process, in which metabolic enzymes, such as proteinases, are activated. As a result of this process, some amino acids and peptides can be released, and the synthesis or utilization of others, to form new proteins, can occur. As a consequence, the nutritional quality of proteins can be enhanced, that is why the germination process is suggested as a technological procedure for improving the nutritional quality of legumes and other seeds [16]. The increase of crude protein at highest level on third day germination are in agreement with other workers [4] for cowpea (72h) and groundbean (72h), respectively. 
Table 1. Effect of germination on proximate composition of fenugreek flours.

\begin{tabular}{llllllll}
\hline Flour & Components & & & & & \\
samples & \% Moisture & \%Ash & \%Protein* & \%Crude Fat & \% Crude Fiber & \%Carbohydrates** & Calorificvalue(Kcal.)/ 100gm) \\
\hline $\mathrm{GFF}_{0}$ & 7.59 & 3.37 & 27.42 & 9.57 & 13.37 & 52.05 & 404.01 \\
$\mathrm{GFF}_{24}$ & 6.02 & 2.95 & 26.10 & 7.69 & 14.70 & 57.24 & 402.57 \\
$\mathrm{GFF}_{48}$ & 6.12 & 2.92 & 29.36 & 8.23 & 12.00 & 53.37 & 404.99 \\
$\mathrm{GFF}_{72}$ & 7.71 & 2.94 & 29.89 & 7.91 & 11.349 & 51.55 & 396.95 \\
\hline
\end{tabular}

*Calculated using the universal conversion factor $6.25, * *$ determined by difference, where: $\mathrm{GFF}_{0}, \mathrm{GFF}_{24}, \mathrm{GFF}_{48}$, and $\mathrm{GFF}_{72}-$ Fenugreek flours germinated for $0,24,48,72$ hours, respectively

The crude fat contents fenugreek seeds ranged from 7.67 to $9.57 \%$. The highest the fat content $(9.57 \%)$ was observed for raw fenugreek followed by $(8.23 \%)$ for germinated fenugreek flour (48h), $7.91 \%$ for $72 \mathrm{~h}$ and the lowest was $7.67 \%$ for $24 \mathrm{hr}$ germination. In the present work the crude fat decreased by $19.85 \%$ from the raw fenugreek seed on germination. Similarly, [11] also reported that crude fat decreased by about $22 \%$ of the original amount on germination.

The carbohydrate contents of fenugreek flours ranged from 51.55 to $57.24 \%$. The highest carbohydrate was reported for germinated fenugreek flour for $24 \mathrm{~h}$ and then decreased as germination time increased. The effects of germination on carbohydrate constituents in seeds are influenced by many factors such as the amount of oxygen and other constituents in the steep medium, the temperature, and the procedure of hydration from dry seed. These factors profoundly influence respiration, and breakdown and synthesis of seed carbohydrates. The decreased carbohydrate content in the sprouted fenugreek flour might be attributed to use of the nutrient as a readily available energy source during sprouting.

The crude fiber contents of raw and germinated fenugreek flour ranged from 11.349 to $14.70 \%$. The highest crude fiber $(14.70 \%)$ was observed for fenugreek flour at 24h germination. This could be due to the dissipation of some of the starchy endosperm during germination which causes apparent increase in seed coat proportion. But as the time of germination increased the crude fiber content slightly decreased. This decrease is accompanied by a drop in galactan content. An enzyme $\alpha$-galactosidase from germinated fenugreek seeds partially attacks galactomannan to yield galactose [12].

The ash content of fenugreek flours decreased as the germination time increased. The highest ash content $(3.37 \%)$ observed for raw fenugreek seed flour and the lowest (2.92\%) was for germinated fenugreek flour (48h). The observed decrease in ash content of fenugreek flour samples during germination might be due to leaching of minerals during steeping and washing [1].

The moisture content of the prepared fenugreek flours ranged from 6.02 to $7.71 \%$. Germinated for $72 \mathrm{~h}$ fenugreek flour had higher content of moisture. The present study exhibited lower moisture than the reported work of \{12], the moisture content of unprocessed (raw), soaked and germinated fenugreek flour increased from 13.70 to $14.20 \%$, respectively on dry weight basis. [2]Reported that the removal of moisture generally increased concentrations of nutrients and can make some nutrients more available. Low moisture content of flours prevents microbial activity and extends the shelf life of the flour.

\subsection{Effect of Germination on Anti-nutritional Reduction of Fenugreek Flours}

Table 2 depicts the anti-nutrient composition of raw and germinated fenugreek seed. Significant quantities of tannic acids have been reported in the raw fenugreek seeds (718.92 $\mathrm{mg} / 100 \mathrm{~g}$ ). In the present study, germination reduced tannin content by more than $77.85 \%$. The observed reduction in tannin content after germination was a result of formation of hydrophobic association of tannins with seed proteins and enzymes. In addition, loss of tannins during germination also may be due to the leaching of tannins into the water [15].

The raw fenugreek seeds contained $64.22 \mathrm{mg} / 100 \mathrm{~g}$ phytate. Comparing the germinated and non-germinated fenugreek seed, the phytate content decreased significantly $(p<0.05)$ from 64.22 to 18.99 with $53.96 \%$ reduction. Because phytate is water soluble, a significant phytate reduction can be realized by discarding the soak water. In addition, decrease in phytic acid content during germination could be due to increase in phytase activity as reported for other germinated cereals including sorghum [16].

Table 2. Effect of germination on the anti-nutritional reduction of fenugreek flours.

\begin{tabular}{lllll}
\hline Composition & $\mathbf{G F F}_{\mathbf{0}}$ & $\mathbf{G F F}_{24}$ & $\mathbf{G F F}_{\mathbf{4 8}}$ & $\mathbf{G F F}_{72}$ \\
\hline Phytate $(\mathrm{mg} / 100 \mathrm{~g})$ & $64.22 \pm 0.01^{\mathrm{d}}$ & $40.22 \pm 0.006^{\mathrm{c}}$ & $38.39 \pm 0.01^{\mathrm{b}}$ & $18.99 \pm 0.01^{\mathrm{a}}$ \\
Tannin $(\mathrm{mg} / 100 \mathrm{~g})$ & $718.92 \pm 0.01^{\mathrm{a}}$ & $159.21 \pm 0.01^{\mathrm{b}}$ & $187.04 \pm 0.01^{\mathrm{c}}$ & $197.62 \pm 0.01^{\mathrm{d}}$ \\
Saponin $(\%)$ & $1.70 \pm 0.10^{\mathrm{a}}$ & $0.98 \pm 0.01^{\mathrm{b}}$ & $0.23 \pm 0.01^{\mathrm{c}}$ & $0.05 \pm 0.01^{\mathrm{d}}$ \\
Alkaloid (\%) & $0.81 \pm 0.01^{\mathrm{d}}$ & $0.52 \pm 0.0^{\mathrm{c}}$ & $0.33 \pm 0.02^{\mathrm{b}}$ & $0.23 \pm 0.01^{\mathrm{a}}$ \\
\hline
\end{tabular}

All values are means of triplicates $\pm \mathrm{SD}$, Levels not connected by same letter in the same row are significantly different, where: $\mathrm{GFF}_{0}, \mathrm{GFF}_{24}, \mathrm{GFF}_{48}, \mathrm{and}$ $\mathrm{GFF}_{72}$ - Fenugreek flours germinated for $0,24,48,72$ hours, respectively.

The saponins content of plant materials is affected by the plant species, genetic origin, the part of the plant being examined, the environmental and agronomic factors associated with growth of the plant, and post-harvest 
treatments such as storage and processing. There can be considerable variation in composition and quantity of saponins in vegetable material from different places [3]. The saponin contents of both raw and germinated fenugreek flour was shown table 2. Data indicated that the saponin content ranged from 0.05 to $1.70 \%$. The raw fenugreek contains higher saponin content (1.7\%).

The total alkaloid content of raw fenugreek flour was $0.81 \%$. And the lowest total alkaloid content 0.23 was observed for $\mathrm{GFF}_{72}$. This gradual decrease in the content of total alkaloids was observed due to alkaloids are water soluble, soaking in water can easily remove them from the whole seed. However; this depends on the type of soaking solution and permeability of the cell wall of the hull. Hence in order to facilitate the removal of alkaloids the cell wall should be damaged [10].

\subsection{Effect of Germination on Micronutrient Composition of Fenugreek Flours}

The raw fenugreek flour had $191.9 \mathrm{mg} / 100 \mathrm{~g}$, $176.0 \mathrm{mg} / 100 \mathrm{~g}, 13.9 \mathrm{mg} / 100 \mathrm{~g}$, and $3.9 \mathrm{mg} / 100 \mathrm{~g}$ of $\mathrm{Ca}, \mathrm{Mg}, \mathrm{Fe}$ and $\mathrm{Zn}$, respectively. But during $48 \mathrm{~h}$ germination time $\mathrm{Fe}$, $\mathrm{Ca}$ and $\mathrm{Zn}$ contents increased significantly as compared to the raw fenugreek seed (Table 3). This may be due to reduction of anti-nutritional contents after germination. While $\mathrm{Mg}$ decreased at this time might be due to increased requirement for nutrients by the growing plant metabolism. A significant variation was noticed in the total amount of minerals within 24,48 and $72 \mathrm{~h}$ germination. Reduction of mineral content because of germination, indicated the transfer of nutrients from the seed material to the growing embryo. Comparatively lower contents of minerals observed during germination might be also due to leaching out of some minerals into the soaking water.

Table 3. Effect of germination on the mineral content of fenugreek flours.

\begin{tabular}{lllll}
\hline Flour samples & Fe(mg/100g) & Ca(mg/100g) & Zn(mg/100g) & Mg(mg/100g) \\
\hline $\mathrm{GFF}_{0}$ & $13.92 \pm 0.028^{\mathrm{a}}$ & $191.93 \pm 0.002^{\mathrm{a}}$ & $3.91 \pm 0.001^{\mathrm{a}}$ & $176.06 \pm 0.085^{\mathrm{a}}$ \\
$\mathrm{GFF}_{24}$ & $11.12 \pm 0.025^{\mathrm{b}}$ & $190.92 \pm 0.098^{\mathrm{a}}$ & $4.75 \pm 0.007^{\mathrm{b}}$ & $176.03 \pm 0.036^{\mathrm{a}}$ \\
$\mathrm{GFF}_{48}$ & $15.02 \pm 0.068^{\mathrm{c}}$ & $191.95 \pm 0.017^{\mathrm{b}}$ & $6.41 \pm 0.095^{\mathrm{c}}$ & $175.37 \pm 0.054^{\mathrm{b}}$ \\
$\mathrm{GFF}_{72}$ & $11.51 \pm 0.038^{\mathrm{d}}$ & $168.88 \pm 0.003^{\mathrm{c}}$ & $4.43 \pm 0.073^{\mathrm{d}}$ & $153.10 \pm 0.141^{\mathrm{c}}$ \\
\hline
\end{tabular}

All values are means of triplicates $\pm \mathrm{SD}$, Levels not connected by same letter in the same column are significantly different, where: $\mathrm{GFF}_{0}, \mathrm{GFF}_{24}, \mathrm{GFF}_{48}$, and $\mathrm{GFF}_{72}$ - Fenugreek flours germinated for $0,24,48,72$ hours, respectively

\subsection{Effect of Germination on Functional Properties of Fenugreek Flours}

The functional properties of flours play important role in the manufacture of products. Table 4 shows the effect of germination on bulk density and dispersibility of fenugreek flours, the control flour had higher bulk density $0.76 \mathrm{~g} / \mathrm{cm}^{3}$ followed by $0.74 \mathrm{~g} / \mathrm{cm}^{3}, 0.72 \mathrm{~g} / \mathrm{cm}^{3}$, and $0.68 \mathrm{~g} / \mathrm{cm}^{3}$ for 24 , 48 and $72 \mathrm{~h}$, respectively. The reduction of bulk density further increased as germination time increased. This could be because germination tend to soften the seeds, thus making milling easier, with smaller particle sizes than unprocessed grain and due to enzymatic breakdown of starch to sugars during germination [9]. The significance of this is that the less bulky flours will have higher nutrient density, since more flour can be packaged in the same given volume. The processed fenugreek flour also had a higher dispersibility in the range of $73.00-92.00 \%$, which was significantly $(p<0.05)$ higher than that of controlled flour $60.67 \%$.

Table 4. Effect of germination on functional properties of fenugreek flours.

\begin{tabular}{lllll}
\hline Flours & Bulk density $\left(\mathbf{g} / \mathbf{c m}^{\mathbf{3}}\right)$ & Water absorption(\%) & Oilabsorption(ml/g $)$ & Dispersibility(\%) \\
\hline $\mathrm{GFF}_{0}$ & $0.76 \pm 0.002^{\mathrm{a}}$ & $401.86 \pm 1.50^{\mathrm{a}}$ & $296.47 \pm 0.72^{\mathrm{a}}$ & $60.67 \pm 0.58^{\mathrm{a}}$ \\
$\mathrm{GFF}_{24}$ & $0.74 \pm 0.002^{\mathrm{a}}$ & $250.07 \pm 1.10^{\mathrm{b}}$ & $346.13 \pm 0.23^{\mathrm{b}}$ & $73.00 \pm 1.00^{\mathrm{b}}$ \\
$\mathrm{GFF}_{48}$ & $0.72 \pm 0.001^{\mathrm{a}}$ & $248.13 \pm 0.85^{\mathrm{b}}$ & $350.67 \pm 0.31^{\mathrm{c}}$ & $82.67 \pm 1.53^{\mathrm{c}}$ \\
$\mathrm{GFF}_{72}$ & $0.68 \pm 0.009^{\mathrm{b}}$ & $245.15 \pm 0.49^{\mathrm{c}}$ & $398.40 \pm 0.35^{\mathrm{d}}$ & $92.00 \pm 1.00^{\mathrm{d}}$ \\
\hline
\end{tabular}

All values are means of triplicates $\pm \mathrm{SD}$, Levels not connected by same letter in the same column are significantly different, where: $\mathrm{GFF}_{0}, \mathrm{GFF}_{24}$, $\mathrm{GFF}_{48}$, and $\mathrm{GFF}_{72}$ - Fenugreek flours germinated for $0,24,48,72$ hours, respectively.

The control fenugreek flour have higher amount of water absorption capacity $(401.86 \%)$. The differences could be attributed to the milling process subjected to each of the flour during processing which resulted in starch damage [18]. The high ratio of galactose substitution contributes to the hydrophilic properties associated with the galactomannans in fenugreek seed. They have a high water-binding capacity and are able to form highly viscous solutions at relatively low concentrations. But on germination the WAC decreased to $250.07,248.13$, and $245.15 \%$ at $24,48,72 \mathrm{~h}$ germination, respectively. In legumes, the endosperm galactomananans are the reserve polysaccharides, which are used up during germination. Germinating legume seeds produce enzymes ( $\beta$-mannase, $\alpha$-galactase) to break down polysaccharide [7]. This is may be the reason for the germination reduces the water absorption capacity of germinated fenugreek flours. In addition to this the solubility of galactomannan in cold water will affect the water absorption of flours.[9]determined theproximatecomposition and physicochemical properties of a protein concentrate prepared from fenugreek (Trigonella Foenumgraecum L.) seed and reported that fenugreek protein concentrate had high oil absorption capacity, water absorption capacity and bulk density. 
The processed fenugreek flour had a higher oil absorption capacity in the range of $346.13-398.40 \mathrm{ml} / \mathrm{g}$, which was significantly $(p<0.05)$ higher than that of control flour. Oil absorption capacity at $0 \mathrm{~h}$ was 296.47 which increased to $346.13,350.67$ and $398.40 \mathrm{ml} / \mathrm{g}$ at 24,48 and $72 \mathrm{~h}$ germination, respectively. Thus, fenugreek flour with high protein and fiber content and coupled with good functionality has a good potential for application in food systems.

\section{Conclusions}

In the developing countries there is an existing dilemma of protein energy malnutrition therefore some new indigenous sources must be exploited against the menace. Present investigation explicated the potential of germination for the preparation of fenugreek flour with better nutritional and functional properties. The study showed that $72 \mathrm{~h}$ of germination of fenugreek flour (GFF72) proved to be the best for highest nutrient content. Functional properties like oil absorption and dispersibilityalso increases after germination which are found to be responsible for preparation of protein enriched products. Therefore, the use of processed fenugreek seed flour can be exploited in functional foods as well as a therapeutic agent on a regular basis.

\section{Acknowledgements}

I express my genuine gratitude toProf. Dr. Yogesh Kumar Jha for his encouragement through kind e-mails and phone calls across the miles starting from the beginning of the work; the support and guidance in the manuscript writing as well as for his encouragement, advice, and concrete support during conducting this thesis work.

My appreciations also go to Addis Ababa University, Institute of Technology, School of Chemical and Bioengineering Department for providing research fund to conduct this research and all Chemical Engineering laboratory staff for their cooperation during my laboratory work.

\section{Appendix}

Photos of activities during laboratory session

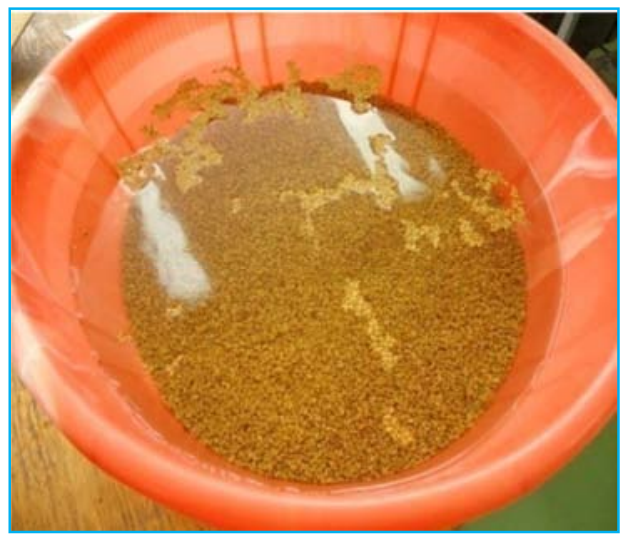

1. Soaking

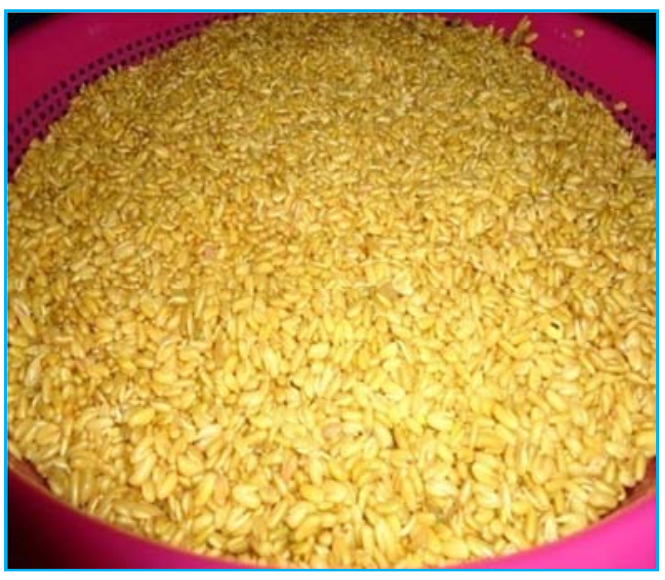

2. Soaked fenugreek

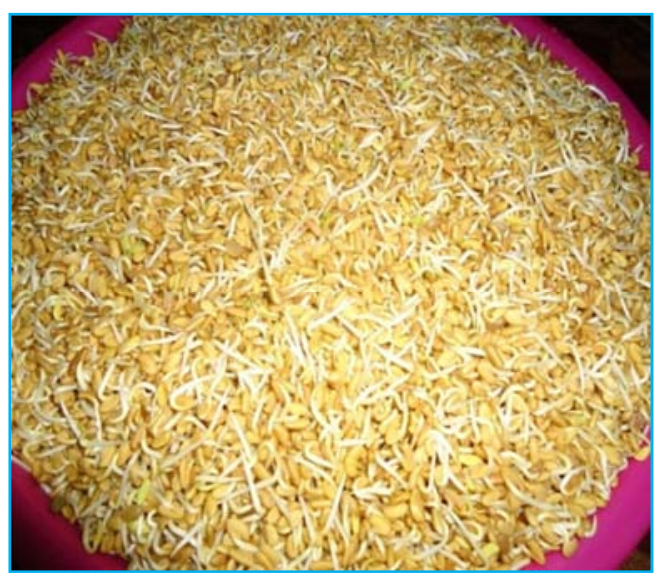

3. Germinated Fenugreek

\section{References}

[1] Ahmadzadeh, R. G. and Prakash, J. (2006). The impact of germination and dehulling on nutrients, antinutrients, invitroiron and calcium bio availability and invitro starch and protein digestibility of some legume seeds.

[2] Amankwah EA, Barimah J, Nuamah AKM, Oldham JH. AndNnaji CO. (2009). Formulation of weaning food from fermented maize, rice, soybean and fishmeal. Pak. J. Nutr., 8(11): 1747-1752.

[3] Ceyhun Sezgin and ArtikN.(2010). Determination of Saponin Content in Turkish Tahini Halvahby Using HPLC, Advance J. of Fo. Sci. and Tech. 2(2): 109-115.

[4] Echendu, C. A., Obizoba, I. C. and Anyika, J. U. (2009). Effects of Germination on Chemical Composition of Groundbean (Kerstingiella geocarpa harm) Seeds, Pak. J. Nutr., 8 (12): 1849-1854.

[5] El-Adawy, T. A., 2002. Nutritional composition and antinutritional factors of chickpeas (Cicerarietinum L.) undergoing different cooking methods andgermination. Pl Food Hum. Nutr., 57: 83-97.

[6] Gall, Alevtina, and Zerihun S. (2009). Ethiopian Traditional and Herbal Medications and their Interactions with Conventional Drugs. EthnoMed. University of Washington. Retrieved on october 13, 2011. 
[7] Mathur V. and Mathur NK. (2005). Fenugreek and other lesser known legume galactomannan-Polysachharides: Scope for developments, J. Sci. Ind. Res. Vol. 64.

[8] Nazar, A., and H. El Tinay. (2007). Functional properties of fenugreek (Trigonella foenum graecum) protein concentrate, Food Chem, 103(2), 582-589.

[9] Paulos, G. and Negussie, R. (2009). Chemical composition and the effects of traditional processing on nutritional composition of gibto (lupinusal bus. l) grown in, Gojam area, Msc thesis. Addis Ababa University.

[10] Shalini, H. and Sudesh, J. (2002). Effect of soaking and germination on nutrient and antinutrient contents of fenugreek (trigonella foenum graecuml.), J. of Fo. Bioch.27; 165-176.

[11] Shalini, H. and Sudesh, J. (2004). Nutritional Evaluation of Wheat-Fenugreek Blends for Product Making. Plant Foods for Human Nutrition 59: 149-154.

[12] Sharma, R. D. (1986). An evaluation of hypocholesterolemic factors of fenugreek seeds in rats, Nutr. Rep. Int. Vol. 34, 669671.

[13] Shimelis, E. A. and S. K. Rakshit. (2008). Influence of natural and controlled fermentations on $\alpha$-galactosides, antinutrients and protein digestibility of beans. International journal of food science and technology 43, 658-666.

[14] Taraseviciene, Z., Honorata, D., Elvyra, J., Aurelija, P., and Marek, G.(2009). Changes in Some Chemical Components During Germination of Broccoli Seeds, Not. Bot. Hort. Agrobot. Cluj 37 (2), 173-176.

[15] Tizazu, S., Urga, K., Abuye, C. and Retta, N.(2010). Improvement of energy and nutrient density of sorghum based complementary foods using germination. African journal of food agriculture nutrition and development 10(8),2928-2942.

[16] Wolf, W. J. (1970. Functional, Chemical and physical properties of soybean protein. Journal of Food and Agriculture 14: 969-976. 